\title{
Norovirus infection in primary immune deficiency
}

Running head: Norovirus in primary immune deficiency

Keywords: norovirus, primary immune deficiency, immunodeficiency

\section{Li-An K Brown ${ }^{1}$, lan Clark², Julianne R Brown ${ }^{3,4}$, Judith Breuer ${ }^{5}$, David M Lowe ${ }^{6 *}$}

1. Royal Free London NHS Foundation Trust, London, NW3 2QG, UK

2. Department of Cellular Pathology, Royal Free London NHS Foundation Trust, London, NW3 2QG, UK

3. Microbiology, Virology and Infection Control, Great Ormond Street Hospital for Children NHS Foundation Trust, London, UK

4. NIHR Biomedical Research Centre at Great Ormond Street Hospital for Children NHS Foundation Trust and University College London, UK

5. Division of Infection and Immunity, University College London, London, UK

6. Institute of Immunity and Transplantation, University College London, Royal Free Campus, London, NW3 2QG, UK

* Corresponding author: d.lowe@ucl.ac.uk 


\section{Abstract}

Norovirus is acknowledged to be a leading cause of acute gastroenteritis worldwide and its importance as a cause of chronic infection in immune deficient hosts is increasingly recognised. Current evidence suggests that a co-ordinated response of innate immune mechanisms, CD8+ cytotoxicity and a humoral response, with CD4+ orchestration, is necessary for norovirus clearance. We explain how primary immune deficiency impairs these host defences and predisposes to chronic infection, associated with protracted diarrhoea, weight loss, and requirement for parenteral nutrition. The mucosal villous atrophy frequently seen in norovirus infection appears to be immune-mediated, suggesting that some functional immune response is required in order for chronic norovirus infection to become symptomatic in primary immune deficiency.

We provide a comprehensive summary of published cases of norovirus infection in patients with primary immune deficiency. Spontaneous viral clearance has been described, however the majority of reported cases have had prolonged and severe illness. Treatment strategies are discussed in detail. Approaches which have been tried in patients with primary immune deficiency include exclusion diets, enteral and intravenous immunoglobulins, breast milk, immunosuppressants, ribavirin, and nitazoxanide. To date, only ribavirin has been used with apparent success to achieve clearance of chronic norovirus in primary immune deficiency and randomised controlled trials are needed to evaluate a number of promising therapies that are discussed. 


\section{Abbreviations}

- RNA - ribonucleic acid

- HBGA - histo-blood group antigen

- SCID - severe combined immunodeficiency

- IEL - intra-epithelial lymphocyte

- NKG2D - natural killer group 2D

- $\mathrm{MIC}-\mathrm{MHC}$ class I chain-related protein

- HSCT - haematopoietic stem cell transplant

- CVID - common variable immune deficiency

- IVIG - intravenous immunoglobulin

- $\mathrm{AML}$ - acute myeloid leukaemia

- $\mathrm{mTOR}$ - mammalian target of rapamycin

- $\quad 2 \mathrm{CMC}-\mathrm{2}^{\prime}-\mathrm{C}$-methylcytidine

\section{Introduction}

Noroviruses are positive-stranded RNA viruses from the family Caliciviridae [1]. Human norovirus is a leading cause of epidemic gastroenteritis worldwide, and is often associated with outbreaks in healthcare institutions [2]. In the United States, norovirus is recognised as the leading contributor to acute gastroenteritis across all age groups and causes on average 19-21 million total illnesses each year [3]. There are at least 6 genogroups and greater than 40 genotypes of noroviruses [4]; human infections are most frequently caused by genogroups GII, GI, and to a lesser extent, GIV [5]. Norovirus enters human cells via blood 
group antigens (including $A B O$ and sialyl-Lewis $X$ ), but other receptors such as heparan sulphate may also be important [6]. The mean duration of symptoms in the normal human population is 1.2-2.8 days [7], however significantly more prolonged and severe disease can occur in immune deficient hosts, associated with small bowel villous atrophy and malabsorption $[8,9]$. Indeed, this pathogen may be of especial concern for patients with genetic immune deficiencies which cannot be easily corrected.

Understanding the pathophysiology of human norovirus infection has historically been hampered by a lack of in vitro infection models, as human norovirus cannot be propagated in standard cell culture. Murine norovirus has been widely studied as a surrogate in cell culture and mouse models, although infection only causes clinical disease in immunocompromised mice [10]. Large animal models of human norovirus infection include those created in chimpanzees [11], gnotobiotic pigs [12] and gnotobiotic calves [13], but none of these parallel immunocompromised patients. Recent advances in human norovirus research have included the development of an immune deficient mouse model which can be infected with human norovirus [14] and a human B cell model which can be infected by human norovirus in the presence of histo-blood group antigen (HBGA) -expressing enteric bacteria [15], although this is yet to be successfully replicated in other laboratories [16]. Notwithstanding these limitations, we present here the current understanding of the immune response to norovirus and how primary immune deficiency might subvert host defences to predispose to chronic infection. We summarise clinical reports of norovirus infection in primary immunodeficiency conditions, and discuss potential options for therapy in this challenging population. At the current time, no vaccine or antiviral therapy has been licensed [17]. 
The immune response to norovirus and its compromise in patients with primary immune deficiency

The immunological response to norovirus infection remains incompletely understood (as recently reviewed [18]), with progress thwarted by the lack of available in vitro models. Indeed, even the types of host cell infected by norovirus are not well established - although varying evidence exists for tropism towards mucosal epithelial cells, B cells and antigenpresenting cells $[18,19]$. Nevertheless, it is clear from human studies that there is rapid and broad immune activation in response to infection in immunocompetent hosts, both systemically [20] and in stool [21], with subsequent development of antibody responses.

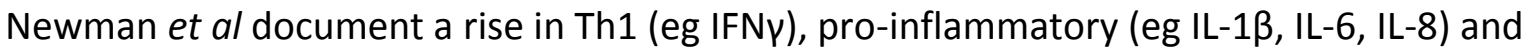
Th2 (eg IL-4, IL-10) cytokines in serum [20], while Ko et al predominantly observed increased IL-2 and IFN $\gamma$ in faeces [21].

In relation to chronic infection in patients with primary immunodeficiency, two aspects are important to understand: by what mechanisms is norovirus usually cleared from the host (and by extrapolation which mechanisms explain failure of clearance), and what is the pathogenesis of mucosal villous atrophy (which underlies malabsorption and thus symptoms)?

Evidence from animal models suggests an important role for antibodies in clearance of infection [12, 22], and their appearance may correlate with virological control. Chachu et al found in a murine model that functional B cells or specific norovirus antibodies could effect viral clearance in RAG-/- combined (B and T cell) immunodeficient mice [23]. However, severe combined immunodeficiency (SCID) children with B cell deficiency had 10-fold lower levels of norovirus than SCID children in whom B cells were intact (perhaps explained by B 
cells acting as a site for viral replication), underlining the complexity of immune responses [24].

Virus-specific CD8+ cytotoxic T cells also contribute significantly to viral clearance in mice $[25,26]$, with perhaps a particular role for perforin [26]. Tomov et al observed that murine norovirus strains achieving chronic infection elicited a poorer CD8+ T cell response in terms of cytokine and granzyme production, and that adoptive transfer of this cell type to RAG -/mice reduced viral shedding [25].

CD4+ T cells also appear important for viral clearance [26] and protective immunity against further infection [27]. These lymphocytes activate antigen presenting cells, facilitate B cell development including antibody class-switching and stimulate cytotoxic T cells. As mentioned above, both Th1 and Th2 cytokines are observed in the robust immune response of normal hosts $[20,21]$, although mouse models suggest that interferon-gamma may be redundant for virological clearance [26].

Type I interferons limit viral replication in vitro [28] and speed clearance in vivo [29], while IFN- $\alpha / \beta R-/-$ mice suffer far higher viral loads than wild-type controls [30]. Recent evidence has also strongly implicated Type III interferons in mice [31, 32], with effective cure of chronically infected animals achieved via administration of IFN- $\lambda$.

In totem, the available data suggest that a co-ordinated response of innate mechanisms (interferons), CD8+ cytotoxicity and a humoral response, presumably with CD4+ orchestration, is associated with norovirus clearance. There may be redundancy within these mechanisms and, although antibody-deficiency is common in patients with chronic infection, it seems likely that an additional component of immunocompromise, most likely 
within the CD4+ T cell compartment, is required. For example, we are not aware of reports of chronic norovirus infection in patients with X-Linked Agammaglobulinemia (pure B cell deficiency).

Despite this requirement for profound immune deficiency to predispose to chronic norovirus infection, evidence from coeliac disease suggests that the mechanisms driving villous atrophy still involve active immunological processes: predominantly those of cytotoxic intraepithelial lymphocytes (IELs) - including perforin, granzyme, Fas Ligand binding to Fas or Natural Killer Group 2D (NKG2D) binding to MHC class I chain-related protein (MIC; as recently reviewed [33]). Biopsies of immunocompetent patients with acute norovirus infection [34] or immunodeficient patients with chronic infection [35] generally reveal increased IELs, and we hypothesise that similar cytotoxic mechanisms to coeliac disease underlie the villous atrophy observed. There is some evidence that double-stranded viral RNA, which forms during the norovirus replication cycle, might be directly toxic to epithelial cells [36], but no definitive proof that such toxicity occurs in humans in vivo.

This suggests that some functional, predominantly cytotoxic, immune response may be required in order for chronic norovirus infection to become symptomatic. Newman et al discovered that symptoms in experimental human norovirus infection correlated with serum cytokine responses rather than viral titres [20]. Accordingly, published [35] and personal observations suggest an apparently paradoxical symptomatic response in some individuals to treatment with immunosuppressive medication. Although high doses of immunosuppressives are clearly deleterious for norovirus control and should be reduced if possible [8], judicious use of low doses may be required in situations of chronic infection and intractable symptoms. 
The mechanism by which cytotoxic T cells may become activated in patients with chronic norovirus infection is unclear, given that compromise of the CD4+ T cell compartment is common in these individuals $[8,18]$. Although direct antigen presentation from infected cells may be important, a highly implicated mediator in coeliac disease is the cytokine IL-15 [33] which activates and upregulates the cytotoxicity of IELs as well as impairing response to regulatory T cells [37]. Importantly, this cytokine is secreted from, and expressed on the surface of, dendritic cells and intestinal epithelial cells [37] and this process may thus be preserved even with severe compromise of CD4 and B cell function. Such a mechanism remains speculative at present and requires further investigation.

Figure 1 summarises our current understanding of the mechanisms of norovirus clearance and where they are likely to be compromised in immunodeficient patients with chronic infection. At present this remains a putative model and is of most relevance to patients with severe enteropathy.

\section{Presentation and complications of norovirus infection in primary immune deficiency}

Primary immune deficiencies are a large, diverse group of disorders classified into major groups of combined immunodeficiencies, combined immunodeficiencies with associated or syndromic features, antibody deficiencies, immune dysregulation, phagocytic defects, defects in innate immunity, autoinflammatory disorders, and complement deficiencies [38]. The commonest symptomatic primary immune deficiency in adults is common variable immune deficiency (CVID). This condition is characterised by a failure in B cell differentiation with defective immunoglobulin production, and co-existing T cell defects are also common [39]. Patients with CVID have a heterogeneous clinical presentation but tend to be susceptible to recurrent infections of the upper and lower respiratory tract, gastrointestinal 
infections, and experience higher frequencies of inflammatory and autoimmune conditions including inflammatory bowel disease [40].

Norovirus infection in hosts with secondary immunocompromise has been described $[8,9]$ and norovirus is recognised to be a frequent enteric pathogen in these patient groups. Norovirus infection in hosts with immune deficiencies is often characterised by a chronic rather than acute course, severe diarrhoea, prolonged viral shedding, and may be complicated by malabsorption, weight loss, organ failure, requirement for parenteral nutrition, and even death [8]. This has been described in patients after solid organ [41-54] and haematopoietic stem cell transplants (HSCT) [46, 53, 55-59], patients with malignancy and those receiving chemotherapy [58-62], patients with chronic lymphocytic leukaemia [63], pre-term infants [64], and in an HIV-positive patient [65].

However, in these secondary immunocompromised states, immunosuppression can often be decreased in response to debilitating infection, or immune reconstitution may be expected to occur, aiding the host response to achieve viral clearance. In contrast, patients with primary immune deficiencies have a stable level of immunodeficiency which may not be easily amenable to correction, and therefore may have a protracted clinical course and inability to clear infection. Table 1 summarises available reports of chronic norovirus infection in patients with primary immune deficiencies.

As with immunocompetent hosts, norovirus infection in primary immunodeficiency may be asymptomatic or symptomatic. A prospective study of the prevalence and clinical consequences of norovirus infection in hospitalised children with varied primary immune deficiencies found norovirus to be the most frequently detected pathogen in faecal samples [66]. Six out of 11 norovirus-infected children had symptoms of diarrhoea, which was 
complicated by dehydration in four cases and malnutrition in two. The longest duration of diarrhoea reported was ten months and in the seven patients followed up with faecal samples, substantial viral excretion was still detected in four after a median of 9.5 months follow up. Two patients with norovirus infection had a detectable norovirus viraemia and one of these also had norovirus detectable in the cerebro-spinal fluid. Upper gastrointestinal endoscopy was performed in three children: two children demonstrated duodenal villous atrophy with moderately higher than normal intraepithelial CD3+ CD8+ lymphocyte counts, one of these cases had slightly higher than normal numbers of apoptotic epithelial cells, with mild polynuclear neutrophil infiltration. In a retrospective series of eight adult patients with CVID and a diagnosis of 'CVID enteropathy', all were found to be positive for norovirus in stool [35]. These patients were all symptomatic with varying severity of diarrhoea, nausea, and weight loss, and five were dependent on parenteral nutrition. One patient appeared to have at least eight years of chronic infection, with detectable norovirus RNA in archived biopsy specimens over this time period. All eight patients had histological findings of duodenal villous atrophy on biopsy. Interestingly, one patient from this series with a two-year history of symptomatic norovirus infection appeared to clear the infection spontaneously with resolution of viral excretion, diarrhoea and vomiting, and normalisation of duodenal villous architecture.

A retrospective audit of patients attending an adult immunology clinic identified three patients with CVID and persistent norovirus infection (defined as two or more positive detections of the same virus more than eight weeks apart) [67]. All three patients were symptomatic with diarrhoea; two patients had severe weight loss (10kg and $8 \mathrm{~kg}$ ) and one 
patient had acute on chronic renal failure, malnutrition and required long-term parenteral nutrition.

One case report describes a patient with CVID who developed a severe protein-losing enteropathy characterised by diarrhoea, nausea, abdominal pain, significant weight loss and requirement for parenteral nutrition, and was found to have a chronic enteral infection with both human parechovirus type 1 and norovirus for at least two years [68]. Biopsies from the oesophagus, antrum, duodenum, distal ileum, colon and sigmoid, all showed lymphocytic infiltration with a marked increase of T cells. The duodenum showed villous atrophy and there was also apoptotic colitis.

Prolonged symptoms of norovirus gastroenteritis have been described in a child with cartilage hair hypoplasia (a rare genetic disorder with autosomal recessive chondrodysplasia and a primary $T$ cell immunodeficiency) who excreted norovirus in the stool for four months before HSCT, then again for five months following HSCT [69]. The child suffered from diarrhoea, vomiting, weight loss, and occasional fever but made a full recovery after immune reconstitution. In this case, HSCT may have enabled viral clearance due to lymphocyte engraftment. In contrast, HSCT has been attributed as a cause of norovirus persistence in some primary immune deficiency patients. Xerry et al described two infants with primary immune deficiency (one with Wiskott-Aldrich syndrome, one with severe combined immunodeficiency syndrome) who underwent HSCT from matched unrelated donors then developed norovirus gastroenteritis post-transplant, on day 11 and day 34 respectively [70]. The infants excreted norovirus for 69 and 48 days and both were found to be excreting 3 unique strains.

\section{Chronic norovirus infection and CVID enteropathy}


A proportion of patients with CVID suffer from a severe chronic enteropathy characterised by diarrhoea and malabsorption [71, 72]. Although the term 'CVID enteropathy' has been used to describe a range of histopathological abnormalities, it is best reserved for those cases with increased IELs, epithelial cell apoptosis and villous atrophy in the small bowel $[73,74]$, similar to changes found in coeliac disease as demonstrated in Figure 2. Despite these histological similarities to coeliac disease, a gluten-free diet rarely improves symptoms in CVID enteropathy [35, 72]. Nevertheless, as serological tests are unhelpful in patients with antibody deficiency, in CVID patients with enteropathy and an appropriate HLA haplotype for coeliac disease a trial of a gluten-free diet is the only way to determine whether there is co-existent CVID and coeliac disease.

Woodward et al recently postulated that chronic norovirus infection may play a major role in the aetiology of severe CVID enteropathy [35]. All eight patients identified with CVID enteropathy in this retrospective series were found to be positive for norovirus in stool, and three patients had clinical resolution and improvement in duodenal villous atrophy when viral clearance was achieved. Conversely, many cases of CVID enteropathy seem to respond symptomatically to immunosuppressive therapies including steroids [72] and anti-TNF therapies [75], although no significant change was seen in histopathological appearance of small bowel biopsies after treatment [75]. These findings may support a role for aberrant, cytotoxic immune responses to chronic norovirus infection, and perhaps other enteric infections, in the aetiology of CVID enteropathy.

\section{Treatment of chronic norovirus infection in immunocompromised hosts}

In immunocompetent patients, the mainstay of therapy for norovirus gastroenteritis remains supportive care during the self-limiting illness. However, chronic infections in 
immunocompromised hosts can lead to severe malabsorption, organ failure, and death, motivating a search for effective treatments. Reducing immunosuppressive therapy in secondary immune deficiency is key to viral clearance $[42-45,47,50]$, but this option is not available for patients with primary immunological defects.

A number of potential treatments for norovirus infection have been evaluated in immune deficient hosts, as summarised in Table 2. Exclusion diets, for example lactose- or glutenfree diets, have not had lasting benefits $[35,65]$. Breast milk, as a source of IgA and lactoferrin, is a potential candidate for norovirus treatment, and may block the interaction of norovirus particles with human HBGA receptors required for entero-invasion [76]. However, trials in two patients had no effect on symptoms or norovirus excretion $[68,77]$. Immunoglobulins appear to be important for clearance of norovirus infection [12, 22], and therefore supplementary immunoglobulins for deficient patients might theoretically aid viral clearance. Immunoglobulins have been administered to patients with chronic norovirus infection either enterally or intravenously. Enteral administration achieves local delivery of immunoglobulins to the intestinal epithelium, and binding of viral particles to enteral antinorovirus immunoglobulins could in theory inhibit viral adherence to intestinal epithelium, as has been demonstrated with rotavirus [78]. However, they may also be susceptible to protein degradation. A number of reports have found a positive benefit from this approach. A retrospective review of 12 transplant recipients with norovirus infection treated with oral immunoglobulins reported success in 11 patients and mild improvement in one [54]. Chagla et al and Ebdrup et al each describe one adult on immunosuppressive therapy after transplant whose chronic norovirus infection disappeared after enteral immunoglobulins [51] [52]. A retrospective audit described limited improvement in two patients with CVID 
and persistent norovirus infection who were given oral immunoglobulin; one patient had symptomatic improvement but ongoing viral excretion until clearance five months later, while the other patient had ongoing requirement for parenteral feeding and detectable viral excretion [67]. Florescu et al reported improvement in symptoms and resolution of viral shedding after treatment with oral immunoglobulin in two children with chronic norovirus infection after small bowel transplantation [48].

A subsequent case-control study with 12 cases of immunocompromised patients with norovirus enteritis found oral immunoglobulin versus no oral immunoglobulin favoured resolution of diarrhoea and decreased stool output after treatment, although this was not statistically significant [79]. Published studies which have failed to find a benefit from enterally-administered immunoglobulins for chronic norovirus infection include two patients with secondary immune deficiency after transplant [77] [50], and two with primary immune deficiencies [68] [66].

Intravenous administration of immunoglobulins has been evaluated for treatment of chronic norovirus infection in several patients but with limited success. After IVIG, Wingfield et al did detect a minimal two-day improvement in symptoms and reduced diarrhoea in one patient with HIV infection [65]. IVIG given to two patients with secondary immune deficiency after transplant was ineffective [77] [50]; IVIG also failed to cure persistent norovirus infection in primary immune deficiencies (one patient with CVID [68], two out of three patients with CVID [67], and three children with inherited immunodeficiencies [66]). Boosting IL-2 activity in immune deficient hosts could be a target for treatment of norovirus infection, because increased stool IL-2 levels have been measured in norovirus infection 
[80]. However, IL-2 therapy was unsuccessful in one patient with HIV infection and symptomatic chronic norovirus infection [65].

Two antiviral therapies have been evaluated for efficacy in norovirus infection in immune deficient hosts. Nitazoxanide is a broad-spectrum antimicrobial agent licenced for the treatment of diarrhoea caused by Cryptosporidium spp. and Giardia lamblia, with anti-viral effects, thought to work through potentiation of host anti-viral activity. It has been shown to inhibit the replication of norovirus in cell lines [81] and reduce the duration of symptoms in human infection [82]. Activity against norovirus infection has been mixed: one immunosuppressed patient with relapsed refractory acute myeloid leukaemia $(A M L)$ and chronic graft-versus-host disease after HSCT achieved complete clinical resolution within four days of starting a course of oral nitazoxanide, although had ongoing asymptomatic viral shedding for over 30 days [83]. Morris \& Morris similarly described a fast clinical response within two to four days of starting oral nitazoxanide in 13 out of 13 immunosuppressed or chemotherapy-receiving patients (3 pre-HSCT, 10 after HSCT), with improvements in diarrhoea, nausea and abdominal pain [59], although the duration of norovirus infection prior to treatment is not stated. There was variable clearance of stool virus, however. Conversely, a transplant recipient [50] and a patient with CVID [67], both with prolonged norovirus gastroenteritis, did not respond to treatment with nitazoxanide.

Ribavirin is a broad-spectrum nucleoside analogue antiviral licenced for treatment of HCV and RSV infections, with in vitro activity against norovirus; additive effects may be seen when combined with interferon-alpha [84]. Its value in the treatment of chronic norovirus infection was assessed by Woodward et al in patients with CVID and enteropathy found to have persistent excretion of norovirus [35]. Two out of five treated patients cleared 
norovirus with complete resolution of clinical symptoms after ribavirin therapy for several months. Out of the remaining three treated patients, two failed to clear the virus despite the addition of interferon-alpha, and one died before the end of treatment. Van de Ven et al did not achieve a change in clinical symptoms or viral load of norovirus in one patient with CVID and co-infection with human parechovirus type 1 and norovirus [68], treated with a 10-day course of ribavirin. Likewise, a two-week course of ribavirin did not affect norovirus excretion in a patient with CVID and chronic norovirus infection [67].

A number of groups have observed the effects of immunosuppressive therapies in immune deficient patients with chronic norovirus infection. Oral steroids showed no benefit in one immunosuppressed post-HSCT patient [55] and one patient with CVID [35], but were associated with a significant improvement in gastrointestinal symptoms and serum albumin, faecal $\alpha 1$-antitrypsin and calprotectin, in one patient with CVID and co-infection with human parechovirus type 1 and norovirus [68]. Azathioprine and anti-TNF therapies were unsuccessful in the treatment of one patient with CVID [35].

It has been suggested that in immunosuppressive regimens, switching one agent from a calcineurin inhibitor to a mammalian target of rapamycin (mTOR) inhibitor may have antiviral effects $[73,74]$, for example as employed in CMV reactivation after solid organ transplant. In two cases of chronic norovirus infection in secondary immune deficiency after transplant, a switch from tacrolimus to an mTOR inhibitor was successful, with resolution of infection [85] [53]. This suggests that sirolimus or similar agents may have a particular role in the management of CVID enteropathy and chronic norovirus infection, both via a directly antiviral effect and suppression of aberrant immune responses. 
Jones et al demonstrated that HBGA-expressing enteric bacteria are necessary for human norovirus infection of B cells in a mouse model, and mouse norovirus replication was reduced in vivo when the intestinal microbiota was depleted by administration of oral antibiotics [15]. However, a retrospective study of renal transplant recipients which identified 15 patients with norovirus infection and one with sapovirus infection, found empirical antimicrobial therapy to be unsuccessful in four out of four patients [42], and a prolonged course of antibiotic treatment for methicillin-resistant Staphylococcus aureus chest infection and Clostridium difficile in a CVID patient with persistent norovirus, had no effect on viral excretion [67].

Furthermore, there are several potential candidates for treatment of chronic norovirus infection which have not yet been evaluated in immune deficient patients $[17,86]$. A promising drug is the nucleoside analogue favipiravir, a broad-spectrum antiviral agent which may have multiple mechanisms of action [87]. In vitro, it has modest potency again murine norovirus in a cell culture model [88], and treatment of murine norovirus-infected mice caused more rapid clearance rates of infectious virus via induction of lethal mutagenesis, with higher mutagenic activity and greater efficiency in controlling viral titres than was seen for ribavirin [89]. Due to its current status in development for use in influenza, favipiravir has been administered to greater than 1400 human subjects in clinical trials, with proven safety and tolerability [90], however is not yet available for clinical use in norovirus infections.

Another nucleoside analogue with possible future use in human norovirus infection is $2^{\prime}-C$ methylcytidine $(2 \mathrm{CMC})$ and its derivatives. $2 \mathrm{CMC}$ has been shown to have anti-murine norovirus activity in cell culture [91] and to be a potent inhibitor of human norovirus 
replication in a replicon cell culture model $[92,93]$ and in a B cell culture system [94]. In mouse models, $2 \mathrm{CMC}$ inhibited murine norovirus replication and protected against diarrhoea and mortality [93], as well as reducing viral shedding and transmission [95]. 2CMC was developed as a direct-acting antiviral agent for HCV infection, but has not yet been approved for treatment [17]. Pharmacokinetic studies have shown low oral bioavailability of 2CMC leading to efforts to design prodrugs [96], however further development has been hampered by the unfavourable toxicity profiles of some agents, which frequently cause gastrointestinal side effects $[97,98]$.

Focussing on the host response to infection, IFN- $\lambda$ has been shown in a mouse model to cure persistent murine norovirus infection in the absence of adaptive immunity [32]. IFN- $\lambda$ is an attractive candidate for treatment of human norovirus infection because it has already been used as therapy for chronic HCV infection in Phase II clinical trials [99]. An alternative approach for norovirus drug design is to target the binding of norovirus particles to HBGA carbohydrates, either using small compounds [100, 101], monoclonal antibodies [102-104], or single chain antibody fragments [105]. Therapies based on these approaches remain in the early stages of development.

\section{Conclusion and future directions}

Norovirus infection in primary immune deficiency can cause protracted diarrhoea with frequent need for parenteral nutrition, and may play a central role in the pathogenesis of CVID enteropathy. The severe and complicated course of chronic norovirus infection in patients with primary immune deficiency highlights the need for effective antiviral therapies. To date, only ribavirin has been used successfully to achieve clearance of chronic norovirus in primary immune deficiency. Experience from patients with secondary immune 
deficiencies suggests that nitazoxanide may be of value in the treatment of chronic norovirus, however, randomised controlled trials are needed to evaluate a number of promising therapies. 


\section{References}

1. Fauquet, C.M., et al., Virus taxonomy: VIIIth report of the International Committee on Taxonomy of Viruses. 2005: Academic Press.

2. Robilotti, E., S. Deresinski, and B.A. Pinsky, Norovirus. Clin Microbiol Rev, 2015. 28(1): p. 13464.

3. Hall, A.J., et al., Norovirus disease in the United States. Emerg Infect Dis, 2013. 19(8): p. 1198-1205.

4. Zheng, D.-P., et al., Norovirus classification and proposed strain nomenclature. Virology, 2006. 346(2): p. 312-323.

5. Lindesmith, L.C., et al., Mechanisms of Gll.4 Norovirus Persistence in Human Populations. PLoS Med, 2008. 5(2): p. e31.

6. Arias, A., et al., Progress towards the prevention and treatment of norovirus infections. Future microbiology, 2013. 8(11): p. 1475-1487.

7. TSENG, C.Y., et al., Characteristics of norovirus gastroenteritis outbreaks in a psychiatric centre. Epidemiology \& Infection, 2011. 139(02): p. 275-285.

8. Bok, K. and K.Y. Green, Norovirus gastroenteritis in immunocompromised patients. N Engl J Med, 2012. 367(22): p. 2126-32.

9. Green, K.Y., Norovirus infection in immunocompromised hosts. Clin Microbiol Infect, 2014. 20(8): p. 717-23.

10. Wobus, C.E., L.B. Thackray, and H.W. Virgin, Murine norovirus: a model system to study norovirus biology and pathogenesis. Journal of virology, 2006. 80(11): p. 5104-5112.

11. Bok, K., et al., Chimpanzees as an animal model for human norovirus infection and vaccine development. Proceedings of the National Academy of Sciences, 2011. 108(1): p. 325-330.

12. Cheetham, S., et al., Pathogenesis of a genogroup II human norovirus in gnotobiotic pigs. J Virol, 2006. 80(21): p. 10372-81.

13. Souza, M., et al., Pathogenesis and immune responses in gnotobiotic calves after infection with the genogroup II. 4-HS66 strain of human norovirus. Journal of virology, 2008. 82(4): p. 1777-1786.

14. Taube, S., et al., A mouse model for human norovirus. MBio, 2013. 4(4): p. e00450-13.

15. Jones, M.K., et al., Enteric bacteria promote human and mouse norovirus infection of $B$ cells. Science, 2014. 346(6210): p. 755-759.

16. Jones, M.K., et al., Human norovirus culture in B cells. Nature protocols, 2015. 10(12): p. 1939-1947.

17. Thorne, L., A. Arias, and I. Goodfellow, Advances Toward a Norovirus Antiviral: From Classical Inhibitors to Lethal Mutagenesis. Journal of Infectious Diseases, 2016. 213(suppl 1): p. S27S31.

18. Newman, K.L. and J.S. Leon, Norovirus immunology: Of mice and mechanisms. Eur J Immunol, 2015. 45(10): p. 2742-57.

19. Green, K.Y., Editorial Commentary: Noroviruses and B Cells. Clinical Infectious Diseases, 2016. 62(9): p. 1139-1140.

20. Newman, K.L., et al., Norovirus in symptomatic and asymptomatic individuals: Cytokines and viral shedding. Clin Exp Immunol, 2016.

21. Ko, G., et al., Fecal cytokines and markers of intestinal inflammation in international travelers with diarrhea due to Noroviruses. J Med Virol, 2006. 78(6): p. 825-8.

22. Souza, M., et al., Cytokine and antibody responses in gnotobiotic pigs after infection with human norovirus genogroup II.4 (HS66 strain). J Virol, 2007. 81(17): p. 9183-92.

23. Chachu, K.A., et al., Antibody is critical for the clearance of murine norovirus infection. J Virol, 2008. 82(13): p. 6610-7.

24. Brown, J.R., K. Gilmour, and J. Breuer, Norovirus Infections Occur in B-Cell-Deficient Patients. Clinical Infectious Diseases, 2016. 62(9): p. 1136-1138. 
25. Tomov, V.T., et al., Persistent enteric murine norovirus infection is associated with functionally suboptimal virus-specific CD8 T cell responses. J Virol, 2013. 87(12): p. 7015-31.

26. Chachu, K.A., et al., Immune mechanisms responsible for vaccination against and clearance of mucosal and lymphatic norovirus infection. PLoS Pathog, 2008. 4(12): p. e1000236.

27. Zhu, S., et al., Identification of immune and viral correlates of norovirus protective immunity through comparative study of intra-cluster norovirus strains. PLoS Pathog, 2013. 9(9): p. e1003592.

28. Changotra, $\mathrm{H}$., et al., Type I and type II interferons inhibit the translation of murine norovirus proteins. J Virol, 2009. 83(11): p. 5683-92.

29. Jung, K., et al., The effects of simvastatin or interferon-alpha on infectivity of human norovirus using a gnotobiotic pig model for the study of antivirals. PLoS One, 2012. 7(7): p. e41619.

30. Thackray, L.B., et al., Critical role for interferon regulatory factor 3 (IRF-3) and IRF-7 in type I interferon-mediated control of murine norovirus replication. J Virol, 2012. 86(24): p. 1351523.

31. Baldridge, M.T., et al., Commensal microbes and interferon-lambda determine persistence of enteric murine norovirus infection. Science, 2015. 347(6219): p. 266-9.

32. Nice, T.J., et al., Interferon-lambda cures persistent murine norovirus infection in the absence of adaptive immunity. Science, 2015. 347(6219): p. 269-73.

33. Di Sabatino, A., et al., New insights into immune mechanisms underlying autoimmune diseases of the gastrointestinal tract. Autoimmun Rev, 2015. 14(12): p. 1161-9.

34. Troeger, H., et al., Structural and functional changes of the duodenum in human norovirus infection. Gut, 2009. 58(8): p. 1070-7.

35. Woodward, J.M., et al., The role of chronic norovirus infection in the enteropathy associated with common variable immunodeficiency. Am J Gastroenterol, 2015. 110(2): p. 320-7.

36. McAllister, C.S., et al., TLR3, TRIF, and caspase 8 determine double-stranded RNA-induced epithelial cell death and survival in vivo. J Immunol, 2013. 190(1): p. 418-27.

37. Abadie, V. and B. Jabri, IL-15: a central regulator of celiac disease immunopathology. Immunol Rev, 2014. 260(1): p. 221-34.

38. Al-Herz, W., et al., Primary Immunodeficiency Diseases: An Update on the Classification from the International Union of Immunological Societies Expert Committee for Primary Immunodeficiency. Frontiers in Immunology, 2014. 5: p. 162.

39. Tam, J.S. and J.M. Routes, Common variable immunodeficiency. American Journal of Rhinology \& Allergy, 2013. 27(4): p. 260-265.

40. Agarwal, S. and C. Cunningham-Rundles, Autoimmunity in common variable immunodeficiency. Current allergy and asthma reports, 2009. 9(5): p. 347-352.

41. Angarone, M. and M.G. Ison, Diarrhea in solid organ transplant recipients. Curr Opin Infect Dis, 2015. 28(4): p. 308-16.

42. Roos-Weil, D., et al., Impact of norovirus/sapovirus-related diarrhea in renal transplant recipients hospitalized for diarrhea. Transplantation, 2011. 92(1): p. 61-69.

43. Kaufman, S.S., et al., Calicivirus Enteritis in an Intestinal Transplant Recipient. American Journal of Transplantation, 2003. 3(6): p. 764-768.

44. Kaufman, S.S., et al., Characteristics of human calicivirus enteritis in intestinal transplant recipients. Journal of pediatric gastroenterology and nutrition, 2005. 40(3): p. 328-333.

45. Schorn, R., et al., Chronic norovirus infection after kidney transplantation: molecular evidence for immune-driven viral evolution. Clin Infect Dis, 2010. 51(3): p. 307-14.

46. Ye, X., et al., Noroviruses as a Cause of Diarrhea in Immunocompromised Pediatric Hematopoietic Stem Cell and Solid Organ Transplant Recipients. Am J Transplant, 2015. 15(7): p. 1874-81.

47. Westhoff, T.H., et al., Chronic norovirus infection in renal transplant recipients. Nephrology Dialysis Transplantation, 2009. 24(3): p. 1051-1053. 
48. Florescu, D.F., et al., Two cases of Norwalk virus enteritis following small bowel transplantation treated with oral human serum immunoglobulin. Pediatr Transplant, 2008. 12(3): p. 372-5.

49. Lee, B.E., et al., Chronic norovirus and adenovirus infection in a solid organ transplant recipient. The Pediatric infectious disease journal, 2008. 27(4): p. 360-362.

50. Echenique, I., et al., Prolonged norovirus infection after pancreas transplantation: a case report and review of chronic norovirus. Transplant Infectious Disease, 2015.

51. Chagla, Z., et al., Chronic norovirus infection in a transplant patient successfully treated with enterally administered immune globulin. Journal of Clinical Virology, 2013. 58(1): p. 306-308.

52. Ebdrup, L., et al., Devastating diarrhoea in a heart-transplanted patient. J Clin Virol, 2011. 50(4): p. 263-5.

53. Boillat Blanco, N., et al., Chronic norovirus gastroenteritis in a double hematopoietic stem cell and lung transplant recipient. Transplant Infectious Disease, 2011. 13(2): p. 213-215.

54. Gairard-Dory, A.C., et al., Clinical Usefulness of Oral Immunoglobulins in Lung Transplant Recipients With Norovirus Gastroenteritis: A Case Series. Transplantation Proceedings, 2014. 46(10): p. 3603-3605.

55. Roddie, C., et al., Allogeneic hematopoietic stem cell transplantation and norovirus gastroenteritis: a previously unrecognized cause of morbidity. Clinical infectious diseases, 2009. 49(7): p. 1061-1068.

56. Saif, M.A., et al., Chronic norovirus infection in pediatric hematopoietic stem cell transplant recipients: a cause of prolonged intestinal failure requiring intensive nutritional support. Pediatr Transplant, 2011. 15(5): p. 505-9.

57. Doshi, M., et al., An outbreak of norovirus infection in a bone marrow transplant unit. American journal of infection control, 2013. 41(9): p. 820-823.

58. Schwartz, S., et al., Norovirus gastroenteritis causes severe and lethal complications after chemotherapy and hematopoietic stem cell transplantation. Blood, 2011. 117(22): p. 5850-6.

59. Morris, J. and C. Morris, Nitazoxanide Is Effective Therapy for Norovirus Gastroenteritis after Chemotherapy and Hematopoietic Stem Cell Transplantation (HSCT). Biology of Blood and Marrow Transplant, 2015. 21(2): p. S255-S256.

60. Simon, A., et al., Norovirus outbreak in a pediatric oncology unit. Scandinavian journal of gastroenterology, 2006. 41(6): p. 693-699.

61. Ludwig, A., et al., Quantitative detection of norovirus excretion in pediatric patients with cancer and prolonged gastroenteritis and shedding of norovirus. Journal of medical virology, 2008. 80(8): p. 1461-1467.

62. Brown, W. and C.L. Morris, Nitazoxanide Is Effective Therapy For Norovirus Gastroenteritis After Chemotherapy and Hematopoietic Stem Cell Transplantation (HSCT). Blood, 2013. 122(21): p. 4581-4581.

63. Capizzi, T., et al., Chronic diarrhea associated with persistent norovirus excretion in patients with chronic lymphocytic leukemia: report of two cases. BMC infectious diseases, 2011. 11(1): p. 131.

64. Armbrust, S., et al., Norovirus infections in preterm infants: wide variety of clinical courses. BMC research notes, 2009. 2(1): p. 96.

65. Wingfield, T., et al., Chronic norovirus infection in an HIV-positive patient with persistent diarrhoea: a novel cause. J Clin Virol, 2010. 49(3): p. 219-22.

66. Frange, P., et al., Prevalence and clinical impact of norovirus fecal shedding in children with inherited immune deficiencies. J Infect Dis, 2012. 206(8): p. 1269-74.

67. Duraisingham, S.S., et al., Immune deficiency: changing spectrum of pathogens. Clinical \& Experimental Immunology, 2015. 181(2): p. 267-274.

68. Van de Ven, A., et al., Case report-Pleconaril-resistant chronic parechovirus-associated enteropathy in agammaglobulinaemia. Antiviral therapy, 2011. 16(4): p. 611. 
69. Gallimore, C.I., et al., Chronic excretion of a norovirus in a child with cartilage hair hypoplasia (CHH). J Clin Virol, 2004. 30(2): p. 196-204.

70. Xerry, J., et al., Tracking environmental norovirus contamination in a pediatric primary immunodeficiency unit. J Clin Microbiol, 2010. 48(7): p. 2552-6.

71. Teahon, K., et al., Studies on the enteropathy associated with primary hypogammaglobulinaemia. Gut, 1994. 35(9): p. 1244-1249.

72. Malamut, G., et al., The enteropathy associated with common variable immunodeficiency: the delineated frontiers with celiac disease. The American journal of gastroenterology, 2010. 105(10): p. 2262-2275.

73. Khodadad, A., et al., Gastrointestinal manifestations in patients with common variable immunodeficiency. Digestive diseases and sciences, 2007. 52(11): p. 2977-2983.

74. Daniels, J.A., et al., Gastrointestinal tract pathology in patients with common variable immunodeficiency (CVID): a clinicopathologic study and review. The American journal of surgical pathology, 2007. 31(12): p. 1800-1812.

75. Chua, I., et al., Anti-tumour necrosis factor- $\alpha$ therapy for severe enteropathy in patients with common variable immunodeficiency (CVID). Clinical \& Experimental Immunology, 2007. 150(2): p. 306-311.

76. Jiang, X., et al., Human Milk Contains Elements That Block Binding of Noroviruses to Human Histo-Blood Group Antigens in Saliva. Journal of Infectious Diseases, 2004. 190(10): p. 1850-1859.

77. Nilsson, M., et al., Evolution of human calicivirus RNA in vivo: accumulation of mutations in the protruding $P 2$ domain of the capsid leads to structural changes and possibly a new phenotype. Journal of virology, 2003. 77(24): p. 13117-13124.

78. Losonsky, G.A., et al., Oral administration of human serum immunoglobulin in immunodeficient patients with viral gastroenteritis. A pharmacokinetic and functional analysis. Journal of Clinical Investigation, 1985. 76(6): p. 2362.

79. Florescu, D.F., et al., Is there a role for oral human immunoglobulin in the treatment for norovirus enteritis in immunocompromised patients? Pediatr Transplant, 2011. 15(7): p. 71821.

80. Ko, G., et al., Fecal cytokines and markers of intestinal inflammation in international travelers with diarrhea due to noroviruses. Journal of medical virology, 2006. 78(6): p. 825828.

81. Rossignol, J.F., Nitazoxanide: a first-in-class broad-spectrum antiviral agent. Antiviral Res, 2014. 110: p. 94-103.

82. Rossignol, J.F. and Y.M. El-Gohary, Nitazoxanide in the treatment of viral gastroenteritis: $a$ randomized double-blind placebo-controlled clinical trial. Alimentary pharmacology \& therapeutics, 2006. 24(10): p. 1423-1430.

83. Siddiq, D.M., et al., Norovirus gastroenteritis successfully treated with nitazoxanide. Journal of Infection, 2011. 63(5): p. 394-397.

84. Chang, K.-O. and D.W. George, Interferons and ribavirin effectively inhibit Norwalk virus replication in replicon-bearing cells. Journal of virology, 2007. 81(22): p. 12111-12118.

85. Engelen, M.A., S. Gunia, and J. Stypmann, Elimination of norovirus in a chronic carrier under immunosuppression after heart transplantation-effect of everolimus. Transplant International, 2011. 24(11): p. e102-e103.

86. Kaufman, S.S., K.Y. Green, and B.E. Korba, Treatment of norovirus infections: Moving antivirals from the bench to the bedside. Antiviral Research, 2014. 105: p. 80-91.

87. Jin, Z., et al., Biochemical Evaluation of the Inhibition Properties of Favipiravir and 2'-CMethyl-Cytidine Triphosphates against Human and Mouse Norovirus RNA Polymerases. Antimicrobial agents and chemotherapy, 2015. 59(12): p. 7504-7516.

88. Rocha-Pereira, J., et al., Favipiravir (T-705) inhibits in vitro norovirus replication. Biochemical and biophysical research communications, 2012. 424(4): p. 777-780. 
89. Arias, A., L. Thorne, and I. Goodfellow, Favipiravir elicits antiviral mutagenesis during virus replication in vivo. Elife, 2014. 3: p. e03679.

90. Furuta, Y., et al., Favipiravir (T-705), a novel viral RNA polymerase inhibitor. Antiviral research, 2013. 100(2): p. 446-454.

91. Rocha-Pereira, J., et al., Inhibition of norovirus replication by the nucleoside analogue 2'-Cmethylcytidine. Biochemical and biophysical research communications, 2012. 427(4): p. 796800.

92. Costantini, V.P., et al., Antiviral activity of nucleoside analogues against norovirus. Antiviral therapy, 2012. 17(6): p. 981.

93. Rocha-Pereira, J., et al., The viral polymerase inhibitor 2'-C-methylcytidine inhibits Norwalk virus replication and protects against norovirus-induced diarrhea and mortality in a mouse model. Journal of virology, 2013. 87(21): p. 11798-11805.

94. Kolawole, A.O., et al., Inhibition of human norovirus by a viral polymerase inhibitor in the $B$ cell culture system and in the mouse model. Antiviral Research.

95. Rocha-Pereira, J., D. Jochmans, and J. Neyts, Prophylactic treatment with the nucleoside analogue 2'-C-methylcytidine completely prevents transmission of norovirus. Journal of Antimicrobial Chemotherapy, 2014: p. dku363.

96. Pierra, C., et al., Synthesis and pharmacokinetics of valopicitabine (NM283), an efficient prodrug of the potent anti-HCV agent 2'-C-methylcytidine. Journal of medicinal chemistry, 2006. 49(22): p. 6614-6620.

97. Coats, S.J., et al., Chutes and ladders in hepatitis $C$ nucleoside drug development. Antiviral Research, 2014. 102: p. 119-147.

98. Manns, M.P., et al., The way forward in HCV treatment-finding the right path. Nature Reviews Drug Discovery, 2007. 6(12): p. 991-1000.

99. Muir, A.J., et al., A randomized phase $2 b$ study of peginterferon lambda-1a for the treatment of chronic HCV infection. Journal of Hepatology, 2014. 61(6): p. 1238-1246.

100. Zhang, X.-F., et al., Inhibition of histo-blood group antigen binding as a novel strategy to block norovirus infections. PloS one, 2013. 8(7): p. e69379.

101. Feng, X. and X. Jiang, Library screen for inhibitors targeting norovirus binding to histo-blood group antigen receptors. Antimicrobial agents and chemotherapy, 2007. 51(1): p. 324-331.

102. Lindesmith, L.C., et al., Immunogenetic mechanisms driving norovirus GII.4 antigenic variation. PLoS Pathog, 2012. 8(5): p. e1002705.

103. Lochridge, V.P., et al., Epitopes in the P2 domain of norovirus VP1 recognized by monoclonal antibodies that block cell interactions. Journal of General Virology, 2005. 86(10): p. 27992806.

104. Chen, Z., et al., Development of Norwalk virus-specific monoclonal antibodies with therapeutic potential for the treatment of Norwalk virus gastroenteritis. Journal of virology, 2013. 87(17): p. 9547-9557.

105. Garaicoechea, L., et al., Llama nanoantibodies with therapeutic potential against human norovirus diarrhea. PloS one, 2015. 10(8): p. e0133665.

106. Boshuizen, J.A., et al., Changes in small intestinal homeostasis, morphology, and gene expression during rotavirus infection of infant mice. J Virol, 2003. 77(24): p. 13005-16.

107. Andrassy, J., et al., Is Cytomegalovirus Prophylaxis Dispensable in Patients Receiving an mTOR Inhibitor-Based Immunosuppression? A Systematic Review and Meta-Analysis. Transplantation, 2012. 94(12): p. 1208-1217.

108. Webster, A.C., et al., Target of rapamycin inhibitors (sirolimus and everolimus) for primary immunosuppression of kidney transplant recipients: a systematic review and meta-analysis of randomized trials. Transplantation, 2006. 81(9): p. 1234-1248. 
Table 1. Summary of clinical reports of chronic norovirus infection in patients with primary immune deficiencies

\begin{tabular}{|c|c|c|c|c|c|c|}
\hline Author & $\begin{array}{l}\text { Cause of primary immune } \\
\text { deficiency }\end{array}$ & $\mathrm{N}$ & Presentations & Histology & Treatment & Outcomes \\
\hline $\begin{array}{l}\text { Frange et al } \\
{[66]}\end{array}$ & $\begin{array}{l}\text { Severe combined } \\
\text { immunodeficiency, } \\
\text { MHC II expression } \\
\text { deficiency, } \\
\text { Wiskott-Aldrich syndrome, } \\
\text { immunodeficiency, } \\
\text { centrometic region } \\
\text { instability, and facial } \\
\text { anomalies syndrome, } \\
\text { CD40L deficiency, } \\
\text { other combined } \\
\text { immunodeficiency, } \\
\text { Agammaglobulinaemia, } \\
\text { hypogammaglobulinaemia, } \\
\text { defects of phagocyte } \\
\text { number and/or function, } \\
\text { haemophagocytic } \\
\text { lymphohistiocytosis, } \\
\text { congenital dyskeratosis }\end{array}$ & 11 & $\begin{array}{l}6 / 11 \text { patients } \\
\text { had } \\
\text { diarrhoea. } 2 / 8 \\
\text { of those } \\
\text { excreting } \\
\text { norovirus had } \\
\text { viraemia and } \\
\text { one had } \\
\text { norovirus in } \\
\text { the CSF. }\end{array}$ & $\begin{array}{l}1 \text { patient: } \\
\text { normal, } 1 \\
\text { patient: } \\
\text { moderate } \\
\text { oesophagitis } \\
\text { with antral } \\
\text { gastritis and } \\
\text { duodenal } \\
\text { villous } \\
\text { atrophy, } 1 \\
\text { patient: } \\
\text { duodenal } \\
\text { villous } \\
\text { atrophy }\end{array}$ & $\begin{array}{l}3 \text { had high dose IVIG, } 1 \\
\text { also had high dose oral } \\
\text { IG }\end{array}$ & No improvement \\
\hline $\begin{array}{l}\text { Woodward et } \\
\text { al [35] }\end{array}$ & CVID & 8 & $\begin{array}{l}\text { Prolonged } \\
\text { diarrhoea, } \\
\text { nausea, } \\
\text { weight loss. } 1 \\
\text { patient } \\
\text { probably had }\end{array}$ & $\begin{array}{l}\text { All: } \\
\text { duodenal } \\
\text { villous } \\
\text { atrophy }\end{array}$ & $\begin{array}{l}5 \text { treated with ribavirin } \\
\text { (1 had gluten } \\
\text { withdrawal, } \\
\text { elemental diet, oral } \\
\text { budesonide, } \\
\text { prednisolone, }\end{array}$ & $\begin{array}{l}1 \text { spontaneously cleared, } \\
2 / 5 \text { cured after ribavirin, } \\
3 / 5 \text { unsuccessfully treated } \\
\text { with ribavirin ( } 1 \text { died, } 2 \\
\text { failed) }\end{array}$ \\
\hline
\end{tabular}




\begin{tabular}{|c|c|c|c|c|c|c|}
\hline & & & $\begin{array}{l}\text { norovirus- } \\
\text { related } \\
\text { symptoms for } \\
6 \text { years. } 5 / 8 \\
\text { required long } \\
\text { term } \\
\text { parenteral } \\
\text { nutrition. }\end{array}$ & & $\begin{array}{l}\text { azathioprine and anti- } \\
\text { TNF } \alpha \text { antibodies } \\
\text { before this) }\end{array}$ & \\
\hline $\begin{array}{l}\text { Duraisingham } \\
\text { et al [67] }\end{array}$ & CVID & 3 & $\begin{array}{l}\text { All patients } \\
\text { symptomatic. } \\
2 \text { patients had } \\
\text { severe weight } \\
\text { loss. } 1 \text { patient } \\
\text { had acute on } \\
\text { chronic renal } \\
\text { failure, } \\
\text { malnutrition } \\
\text { and required } \\
\text { long-term } \\
\text { parenteral } \\
\text { nutrition. }\end{array}$ & $\begin{array}{l}1 \text { patient: } \\
\text { normal } \\
\text { histology } \\
\text { throughout } \\
\text { GI tract. } \\
1 \text { patient: } \\
\text { duodenal } \\
\text { increased } \\
\text { IELs but } \\
\text { normal villi. } \\
1 \text { patient: } \\
\text { villous } \\
\text { distortion in } \\
\text { the terminal } \\
\text { ileum with } \\
\text { neutrophilic } \\
\text { infiltration } \\
\text { and cryptitis } \\
\text { throughout } \\
\text { the gut. }\end{array}$ & $\begin{array}{l}2 \text { patients required } \\
\text { large increases in IVIG } \\
\text { dose to maintain } \\
\text { trough IgG levels. } \\
1 \text { patient had } 10 \text { days } \\
\text { nitazoxanide ( } 500 \mathrm{mg} \\
\text { twice daily) with no } \\
\text { effect. } 2 \text { patients had } \\
30 \text { days oral Ig with } \\
\text { symptomatic } \\
\text { improvement in } 1 \text { but } \\
\text { persistent viral } \\
\text { excretion. } 1 \text { patient } \\
\text { had } 2 \text { weeks oral } \\
\text { ribavirin ( } 200 \text { mg twice } \\
\text { daily) with persistent } \\
\text { norovirus detected. }\end{array}$ & $\begin{array}{l}1 \text { patient cleared } \\
\text { norovirus after } 9 \text { months. } \\
2 \text { patients still shedding } \\
\text { norovirus after } 30 \text { and } 16 \\
\text { months respectively }\end{array}$ \\
\hline $\begin{array}{l}\text { Van de Ven } \\
\text { et al [68] }\end{array}$ & CVID & 1 & $\begin{array}{l}\text { Co-infection } \\
\text { with human }\end{array}$ & $\begin{array}{l}\text { Lymphocytic } \\
\text { infiltration }\end{array}$ & $\begin{array}{l}\text { Increased frequency of } \\
\text { IVIG, duodenal Ig, }\end{array}$ & $\begin{array}{l}\text { Complete remission not } \\
\text { achieved, persistent high }\end{array}$ \\
\hline
\end{tabular}




\begin{tabular}{|c|c|c|c|c|c|c|}
\hline & & & $\begin{array}{l}\text { parechovirus } \\
\text { type } 1 \text { and } \\
\text { norovirus. } \\
\text { Chronic } \\
\text { diarrhoea, } \\
\text { nausea and } \\
\text { abdominal } \\
\text { pain. Severe } \\
\text { protein-losing } \\
\text { enteropathy } \\
\text { with 19\% } \\
\text { weight loss } \\
\text { and low } \\
\text { serum } \\
\text { albumin. } \\
\text { Requirement } \\
\text { for parenteral } \\
\text { nutrition. }\end{array}$ & $\begin{array}{l}\text { of } \\
\text { oesophagus, } \\
\text { antrum, } \\
\text { duodenum, } \\
\text { distal ileum, } \\
\text { colon and } \\
\text { sigmoid. } \\
\text { Increase of } \\
\text { CD3+CD8- T } \\
\text { cells. } \\
\text { Duodenal } \\
\text { villous } \\
\text { atrophy and } \\
\text { apoptotic } \\
\text { colitis. }\end{array}$ & $\begin{array}{l}\text { duodenal breast milk, } \\
10 \text { day course ribavirin, } \\
\text { all with no effect. } \\
\text { Prednisolone } 1.5 \\
\mathrm{mg} / \mathrm{kg} \text { with } \\
\text { improvement in } \\
\text { symptoms and } \\
\text { laboratory parameters }\end{array}$ & viral loads \\
\hline $\begin{array}{l}\text { Gallimore et } \\
\text { al [69] }\end{array}$ & $\begin{array}{l}\text { Cartilage hair hypoplasia } \\
\text { (before and after HSCT) }\end{array}$ & 1 & $\begin{array}{l}\text { Symptomatic } \\
\text { for } 6 \text { months }\end{array}$ & - & $\mathrm{Nil}$ & Full recovery \\
\hline
\end{tabular}


Table 2. Summary of reported experience of treatment for chronic norovirus infection in immune deficiency

\begin{tabular}{|c|c|c|c|}
\hline Treatment & Theory & Reference & Summary of evidence \\
\hline Lactose-free diet & $\begin{array}{l}\text { Lactase enzyme located in } \\
\text { distal villus and likely to be } \\
\text { disrupted by villous atrophy } \\
\text { [106] }\end{array}$ & Wingfield et al [65] & $\begin{array}{l}1 \text { patient with HIV infection and symptomatic norovirus infection } \\
\text { for } 15 \text { months. Lactose-free diet had no effect on symptoms. }\end{array}$ \\
\hline Gluten-free diet & $\begin{array}{l}\text { Histological appearances of } \\
\text { duodenal villous atrophy and } \\
\text { symptoms of malabsorption } \\
\text { are similar to those seen in } \\
\text { coeliac disease }\end{array}$ & $\begin{array}{l}\text { Woodward et al } \\
\text { [35] }\end{array}$ & $\begin{array}{l}8 \text { patients with CVID and enteropathy found to have persistent } \\
\text { excretion of norovirus. All underwent trial of gluten withdrawal. } 1 \\
\text { patient had short-term benefit then relapsed. }\end{array}$ \\
\hline \multirow[t]{2}{*}{ Breast milk } & \multirow{2}{*}{$\begin{array}{l}\text { Source of IgA and } \\
\text { lactoferrin. May block } \\
\text { interaction of norovirus } \\
\text { particles with human HBGA } \\
\text { receptors [76] }\end{array}$} & Nilsson et al [77] & $\begin{array}{l}1 \text { patient on immunosuppressive therapy after heart transplant, } \\
\text { also haemodialysis-dependent. Breast milk } 125 \mathrm{ml} \text { given } 3 \text { times } \\
\text { per day for } 3 \text { weeks. No effect on symptoms or viral excretion. }\end{array}$ \\
\hline & & $\begin{array}{l}\text { Van de Ven et al } \\
{[68]}\end{array}$ & $\begin{array}{l}1 \text { patient with CVID and co-infection with human parechovirus } \\
\text { type } 1 \text { and norovirus. Given breast milk } 1 \text { litre daily via duodenal } \\
\text { tube with additional lactoferrin. No change in clinical symptoms } \\
\text { or viral loads of HPeV and norovirus. }\end{array}$ \\
\hline \multirow{2}{*}{$\begin{array}{l}\text { Enteral } \\
\text { immunoglobulin }\end{array}$} & \multirow{2}{*}{$\begin{array}{l}\text { Local delivery of } \\
\text { immunoglobulins to } \\
\text { intestinal epithelium. } \\
\text { Binding of viral particles to } \\
\text { enteral anti-norovirus } \\
\text { immunoglobulins might } \\
\text { inhibit viral adherence to } \\
\text { intestinal epithelium }\end{array}$} & Florescu et al [48] & $\begin{array}{l}2 \text { patients on immunosuppressive therapy after small bowel } \\
\text { transplantation. Given oral immunoglobulin } 25 \mathrm{mg} / \mathrm{kg} \text { every } 6 \mathrm{~h} \\
\text { for } 48 \mathrm{~h} .1 \text { patient had decreased stool output and improved } \\
\text { consistency, } 1 \text { patient had a transient decrease in stool output } \\
\text { only. }\end{array}$ \\
\hline & & Florescu et al [79] & $\begin{array}{l}\text { Retrospective case control study of } 12 \text { cases. Oral } \\
\text { immunoglobulin vs no oral immunoglobulin favoured resolution }\end{array}$ \\
\hline
\end{tabular}




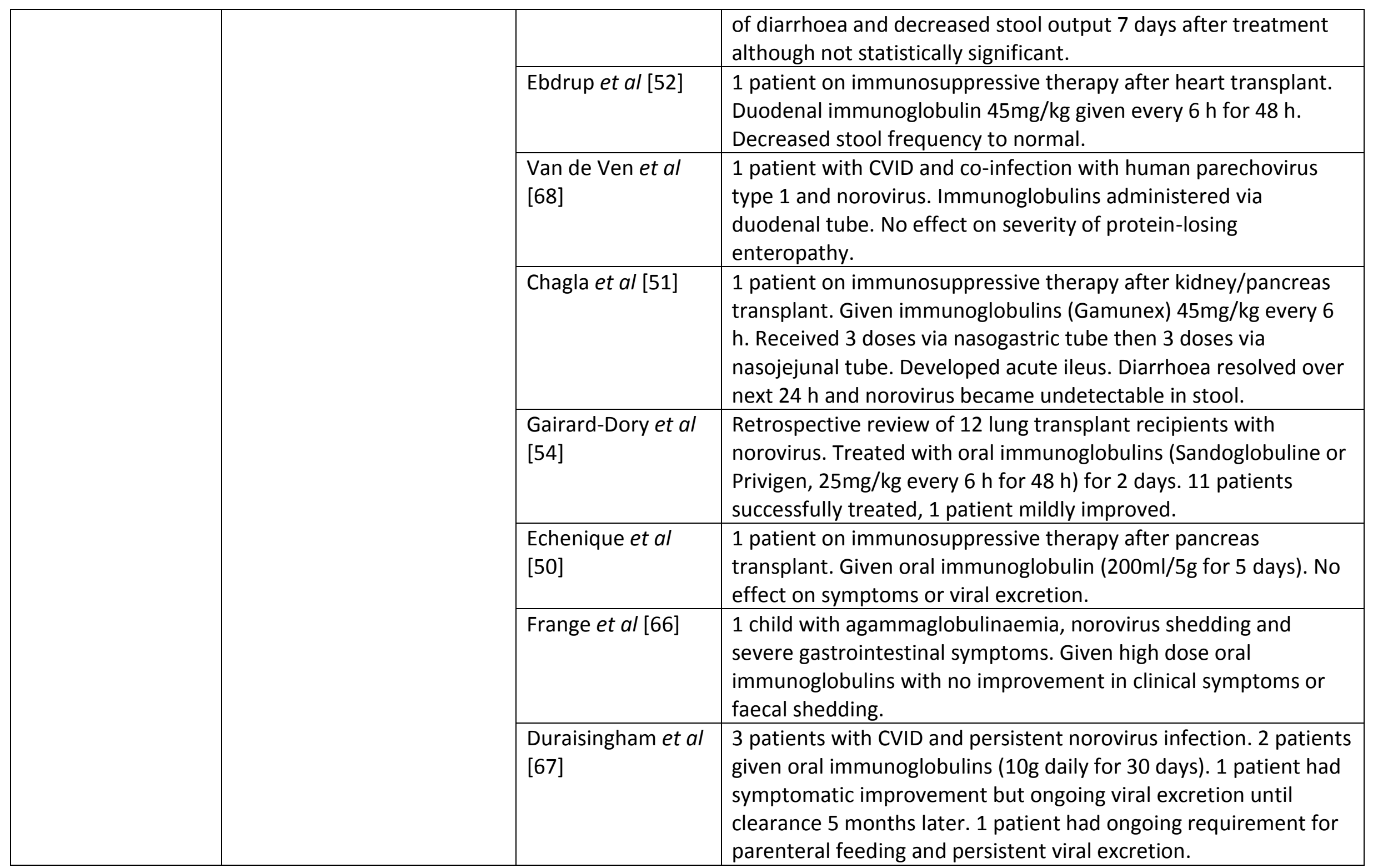




\begin{tabular}{|c|c|c|c|}
\hline \multirow[t]{4}{*}{$\begin{array}{l}\text { Intravenous } \\
\text { immunoglobulin } \\
\text { (IVIG) }\end{array}$} & \multirow{4}{*}{$\begin{array}{l}\text { Immunoglobulins are } \\
\text { important for clearance of } \\
\text { norovirus infection }[12,22] \\
\text { and pooled } \\
\text { immunoglobulins may } \\
\text { contain neutralising } \\
\text { antibodies }\end{array}$} & Nilsson et al [77] & $\begin{array}{l}1 \text { patient on immunosuppressive therapy after heart transplant, } \\
\text { also haemodialysis dependent. IVIG } 0.4 \mathrm{~g} / \mathrm{kg} \text { for } 5 \text { days. No effect } \\
\text { on symptoms or viral excretion. }\end{array}$ \\
\hline & & Wingfield et al [65] & $\begin{array}{l}1 \text { patient with HIV infection and symptomatic norovirus infection } \\
\text { for } 15 \text { months. } 3 \text { days of IVIG given with a minimal 2-day } \\
\text { improvement in symptoms and reduced diarrhoea. }\end{array}$ \\
\hline & & $\begin{array}{l}\text { Van de Ven et al } \\
{[68]}\end{array}$ & $\begin{array}{l}1 \text { patient with CVID and co-infection with human parechovirus } \\
\text { type } 1 \text { and norovirus. Increased dose and frequency of IVIG } \\
\text { infusion (IgG trough levels }>20 \mathrm{~g} / \mathrm{I}) \text {. No effect on severity of } \\
\text { protein-losing enteropathy. }\end{array}$ \\
\hline & & $\begin{array}{l}\text { Duraisingham et al } \\
\text { [67] }\end{array}$ & $\begin{array}{l}3 \text { patients with CVID and persistent norovirus infection. } 2 \text { patients } \\
\text { required large increases in IVIG dose to maintain trough IgG } \\
\text { levels. } 1 \text { of these cleared norovirus after } 9 \text { months. The remaining } \\
2 \text { patients were still shedding norovirus after } 30 \text { and } 16 \text { months } \\
\text { respectively. }\end{array}$ \\
\hline Interleukin-2 & $\begin{array}{l}\text { Increased stool IL-2 levels } \\
\text { measured in norovirus } \\
\text { infection [80] }\end{array}$ & Wingfield et al [65] & $\begin{array}{l}1 \text { patient with HIV infection and symptomatic norovirus infection } \\
\text { for } 15 \text { months. IL-2 therapy unsuccessful. }\end{array}$ \\
\hline
\end{tabular}




\begin{tabular}{|c|c|c|c|}
\hline \multirow[t]{3}{*}{ Nitazoxanide } & \multirow[t]{3}{*}{$\begin{array}{l}\text { Broad-spectrum } \\
\text { antimicrobial agent with } \\
\text { anti-viral effects. Thought to } \\
\text { potentiate host anti-viral } \\
\text { activity. Shown to inhibit } \\
\text { replication of norovirus in } \\
\text { cell lines [81] and reduce } \\
\text { duration of symptoms in } \\
\text { human infection [82] }\end{array}$} & Siddiq et al [83] & $\begin{array}{l}1 \text { patient with relapsed refractory AML with chronic GVHD after } \\
\text { HSCT. On treatment with ponatinib (oral BCR-ABL tyrosine kinase } \\
\text { inhibitor) and immunosuppressive therapy. Given oral } \\
\text { nitazoxanide } 500 \mathrm{mg} \text { twice daily for } 7 \text { days. Complete clinical } \\
\text { resolution within } 4 \text { days but ongoing asymptomatic shedding for } \\
>30 \text { days. }\end{array}$ \\
\hline & & $\begin{array}{l}\text { Echenique et al } \\
\text { [50] }\end{array}$ & $\begin{array}{l}1 \text { patient on immunosuppressive therapy after pancreas } \\
\text { transplant. Given oral nitazoxanide ( } 500 \mathrm{mg} \text { daily for } 5 \text { days). No } \\
\text { effect on symptoms or viral excretion. }\end{array}$ \\
\hline & & $\begin{array}{l}\text { Morris \& Morris } \\
\text { [59] }\end{array}$ & $\begin{array}{l}13 \text { patients on immunosuppressive therapy or chemotherapy ( } 3 \\
\text { pre-HSCT, } 10 \text { after HSCT). Given oral nitazoxanide (dose } \\
\text { dependent on age). All had clinical response with improvements } \\
\text { in diarrhoea, nausea and abdominal pain within } 2-4 \text { days. } \\
\text { Variable clearance of stool virus: } 2 / 3 \text { pre-HSCT became negative } \\
\text { within } 5-14 \text { days of treatment. Post-HSCT: } \\
4 \text { had persistent viral shedding, } 4 \text { came off therapy and remained } \\
\text { negative, } 2 \text { received drug until death ( } 1 \text { adenovirus, } 1 \text { congestive } \\
\text { heart failure) }\end{array}$ \\
\hline
\end{tabular}




\begin{tabular}{|c|c|c|c|}
\hline & & $\begin{array}{l}\text { Duraisingham et al } \\
\text { [67] }\end{array}$ & $\begin{array}{l}3 \text { patients with CVID and persistent norovirus infection. } 1 \text { patient } \\
\text { given oral nitazoxanide } 500 \mathrm{mg} \text { twice daily for } 10 \text { days with no } \\
\text { effect on symptoms or viral excretion. }\end{array}$ \\
\hline \multirow[t]{3}{*}{$\begin{array}{l}\text { Ribavirin +/- } \\
\text { interferon alpha }\end{array}$} & \multirow[t]{3}{*}{$\begin{array}{l}\text { Ribavirin (nucleoside } \\
\text { analogue) has activity } \\
\text { against norovirus in vitro. } \\
\text { Additive effects with INF- } \alpha \\
\text { [84] }\end{array}$} & $\begin{array}{l}\text { Woodward et al } \\
\text { [35] }\end{array}$ & $\begin{array}{l}8 \text { patients with CVID and enteropathy found to have persistent } \\
\text { excretion of norovirus. } 5 \text { treated with oral ribavirin (target levels } \\
\text { of } 1500 \mathrm{ng} / \mathrm{ml} \text { ). } 2 \text { patients cleared norovirus with complete } \\
\text { resolution of symptoms. } 3 \text { patients treated unsuccessfully ( } 2 \text { : } \\
\text { failure of clearance despite addition of interferon alpha, 1: died } \\
\text { before end of treatment) }\end{array}$ \\
\hline & & $\begin{array}{l}\text { Van de Ven et al } \\
\text { [68] }\end{array}$ & $\begin{array}{l}1 \text { patient with CVID and co-infection with human parechovirus } \\
\text { type } 1 \text { and norovirus. 10-day course of ribavirin. No change in } \\
\text { clinical symptoms or viral loads of HPeV and norovirus. }\end{array}$ \\
\hline & & $\begin{array}{l}\text { Duraisingham et al } \\
\text { [67] }\end{array}$ & $\begin{array}{l}3 \text { patients with CVID and persistent norovirus infection. } 1 \text { patient } \\
\text { given } 2 \text { week course of oral ribavirin ( } 200 \mathrm{mg} \text { twice daily) to treat } \\
\text { concurrent RSV infection. No effect on norovirus excretion. }\end{array}$ \\
\hline \multirow[t]{4}{*}{$\begin{array}{l}\text { Immunosuppressive } \\
\text { therapy }\end{array}$} & \multirow{4}{*}{$\begin{array}{l}\text { The aberrant immune } \\
\text { response to norovirus } \\
\text { infection could drive villous } \\
\text { atrophy and symptoms. } \\
\text { Switching from calcineurin } \\
\text { to mTOR inhibitor may have } \\
\text { antiviral effects [107, 108]. }\end{array}$} & Roddie et al [55] & $\begin{array}{l}12 \text { patients with norovirus gastroenteritis after allogeneic HSCT. } 1 \\
\text { patient had prolonged steroid treatment for presumed gut GVHD, } \\
\text { experienced severe weight loss and required parenteral nutrition. }\end{array}$ \\
\hline & & $\begin{array}{l}\text { Woodward et al } \\
\text { [35] }\end{array}$ & $\begin{array}{l}8 \text { patients with CVID and enteropathy found to have persistent } \\
\text { excretion of norovirus. } 1 \text { patient was treated with oral } \\
\text { budesonide, prednisolone, azathioprine and anti-TNF } \alpha \text { antibodies } \\
\text { with no benefit. }\end{array}$ \\
\hline & & $\begin{array}{l}\text { Van de Ven et al } \\
\text { [68] }\end{array}$ & $\begin{array}{l}1 \text { patient with CVID and co-infection with human parechovirus } \\
\text { type } 1 \text { and norovirus. Given prednisolone } 1.5 \mathrm{mg} / \mathrm{kg} \text {. Significant } \\
\text { improvement in gastrointestinal symptoms and improvement in } \\
\text { serum albumin, faecal } \alpha 1 \text {-antitrypsin and calprotectin. }\end{array}$ \\
\hline & & Boillat Blanco et al & 1 patient on immunosuppressive therapy after HSCT and lung \\
\hline
\end{tabular}




\begin{tabular}{|c|c|c|c|}
\hline & & [53] & $\begin{array}{l}\text { transplant with } 6 \text { months chronic norovirus infection. Switched } \\
\text { from tacrolimus to sirolimus with resolution of infection. }\end{array}$ \\
\hline Antibiotics & $\begin{array}{l}\text { Murine norovirus replication } \\
\text { is reduced in vivo when } \\
\text { intestinal microbiota is } \\
\text { depleted by oral antibiotics } \\
\text { [15] }\end{array}$ & $\begin{array}{l}\text { Roos-Weil et al } \\
\text { [42] }\end{array}$ & $\begin{array}{l}16 \text { patients on immunosuppressive therapy after renal transplant } \\
\text { ( } 15 \text { with norovirus infection, } 1 \text { with sapovirus). } 4 \text { patients treated } \\
\text { with empiric antimicrobial therapy with no success. }\end{array}$ \\
\hline
\end{tabular}




\section{Figure Legends}

Figure 1. Putative model of the immune response to norovirus and its dysfunction in primary immune deficiency. Norovirus (blue stars) infects antigen presenting cells (APC), B cells (potentially via the B cell receptor, $B C R$ ) or epithelial cells, where it may contribute to direct cytotoxicity. Infected cells release type I and type III interferons. Norovirus antigen is presented from infected cells via major histocompatibility complex (MHC) I to CD8+ T cells, or via MHC II (on APCs and B cells) to CD4+ T cells. IL-15 expression, especially on epithelial cells, may further activate T cells. CD8+ T cells effect cytotoxicity, particularly as intraepithelial lymphocytes (IEL) inducing apoptosis in mucosal epithelial cells via release of granzyme and perforin, Fas/Fas Ligand binding and Natural Killer Group 2D (NKG2D)-MHC class I chain-related protein (MIC) interaction. CD4+ T cells proliferate and release cytokines to enhance APC activity, CD8+ T cell cytotoxicity and production of antibodies by B cells and plasma cells. This coordinated immune response eliminates norovirus in immunocompetent hosts. Disorders such as common variable immunodeficiency may compromise (1) differentiation of B cells into plasma cells and production of neutralising antibodies, (2) the interaction between T cells and B cells, (3) and CD4+ T cell cytokine release and proliferation. This results in failure to clear norovirus and a persistent, unchecked CD8+ cytotoxic $T$ cell response causing epithelial damage 
Figure 2. Histological appearances of mucosa in chronic norovirus infection. Formalinfixed, paraffin-embedded duodenal biopsy tissue was cut to 3 micron thickness and stained with haemotoxylin and eosin. Panels represent 100x magnification images of $(A)$ healthy individual with normal villous architecture, (B) Common Variable Immunodeficiency (CVID) patient with chronic norovirus infection, demonstrating villous atrophy and intraepithelial lymphocytosis, and (C) coeliac disease patient demonstrating similar appearances to (B). 
Figure 1

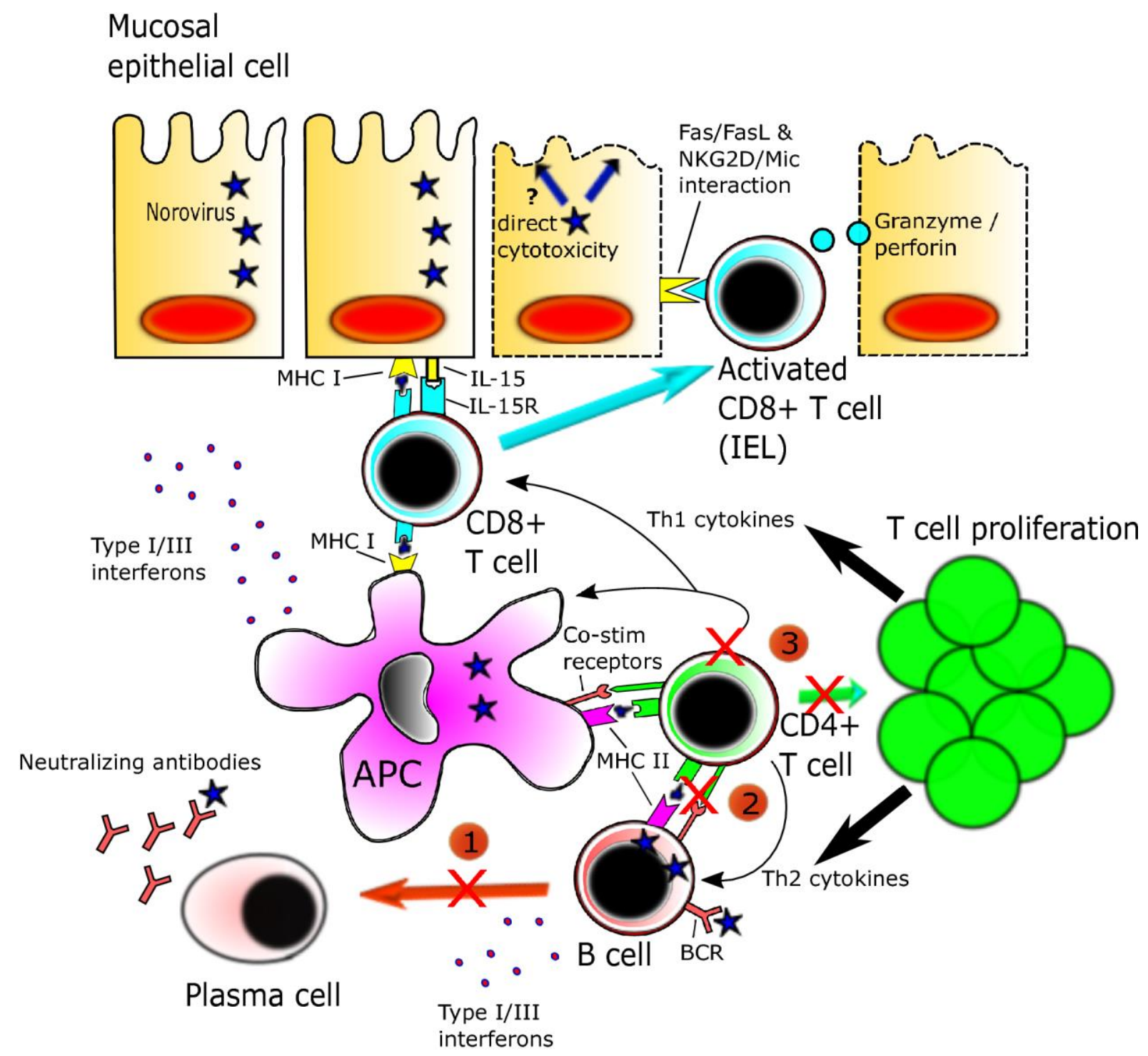


Figure 2

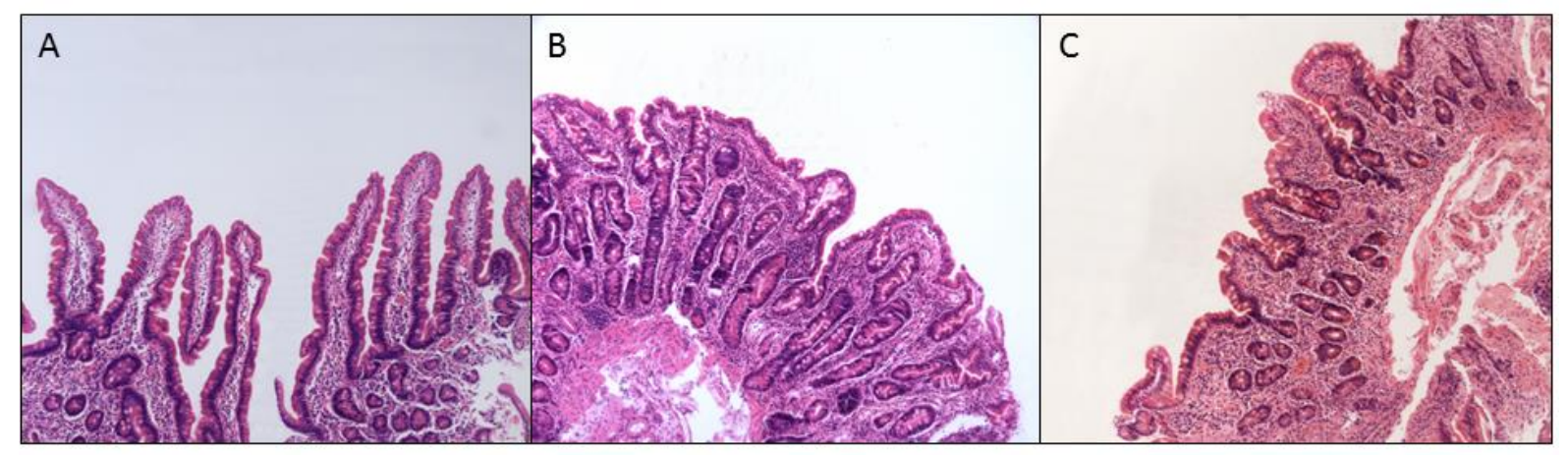

